sonian; perhaps Aristotelian might have been the more exact description.

It is probable that his final orientation was determined at the time, and by the occasion, of the wellknown controversy, now almost forty years old and somewhat outdated, between him and C. Spearman, concerning the latter's theory of the general and the specific factors that enter into mental ability and are presumed to explain certain properties of the correlation tables derived from test scores. Thomson's own theory, antithetical to Spearman's, was a manyfactor sampling theory; but he always preserved a mind open to various later explanations. His mature views are to be found in his book, "The Factorial Analysis of Human Ability", published in 1939.

In 1920 Thomson was appointed to the chair of education at Newcastle, a post which he held for five years, one session being spent in America, where he was always persona gratissima. It was during these years that he devised the Northumberland Tests, designed to select children for the advantages of free secondary education. His motive here, as always, was the securing of justice for all classes of the community.

In 1925 he was appointed professor of education in the University of Edinburgh and director of Moray House Training College, an arduous double office which he held until his retirement in 1951. It is remarkable that in spite of the exorbitant demands of administration and of numberless extraneous committees, he still found time to write papers and books. During this period the Northumberland Tests evolved into the Moray House Tests. Characteristically, he refused to accept personal benefit from these, establishing a trust which administered the proceeds towards educational research.

In the two great surveys, in 1932 and 1947, of the intelligence of a complete age-group of all Scottish children, with sociological and other implications, Thomson was chairman of the Mental Survey Committee. Many other chairmanships and secretaryships, of the Committee of Sociology under the Colonial Research Council, of the Twelfth International Congress of Psychology, the British Psychological Society, the Psychology Section of the British Association and so on, make it very apparent that Thomson, a man of pre-eminent public spirit, never spared himself.

A knighthood was conferred upon him in 1949, the culmination of many distinctions. These were worn so lightly that in his presence they were forgotten. Both personally and as an educationist he was known and respected throughout the world; tall, sparebuilt, alert of glance and quick of speech ; forthright, endlessly generous and sympathetic. His work remains and will be remembered; but still more one will remember the man.

A. C. Artken

\section{Prof. C. O. Bannister}

$\mathrm{By}$ the death on February 22 of Charles Olden Bannister, professor emeritus of metallurgy in the University of Liverpool, at the age of seventy-eight, the teaching and practice of metallurgy loses one of its few remaining links with the closing years of the past century, when such far-reaching changes were taking place in regard to what should constitute the curricula of courses for students in that branch of technology. In fact, metallurgy, as a subject, apart from the operations of smelting and recovery, was only just beginning to be recognized as an essential adjunct to successful engineering practice. In this rapidly widening conception of what metallurgy should stand for, Bannister had played a distinguished part.

With a sound basis of practical chemistry before going to the Royal College of Science in 1896, he had there the unique advantage of coming under the direct tutelage of Prof. W. A. Tilden and a brilliant group of lecturers and demonstrators which included William Palmer Wynne, Martin O. Forster and J. S. S. Brame, all of whom achieved distinction in wider fields in later years. Electing to take the associateship of the Royal Sehool of Mines in metallurgy, Bannister then came under the inspiring influence of Roberts-Austen, whose teaching and researches had already pointed the way to the future scope of metallurgy. After heading the list in his year (1899), with the award of the Bessemer Medal, he remained at the School as an instructor in assaying, first under the professorship of Roberts-Austen (until his death in 1902) and then under his successor, Prof. William Gowland. During this period, when he was closely associated with the late W. H. Merrett, he received the postgraduate award of an 'honours' associateship. Then, in 1903, the opportunity came to transfer his activities to the City of London where, a few years previously, the considerable enlargement of a very old city foundation in Aldgate had led to the creation of the Sir John Cass Technical Institute. There, as head of the Metallurgical Department, Bannister built up, during the next sixteen years, what became an outstanding school of metallurgy in the Metropolis.

During his tenure of this post Bannister was also closely associated, as a consultant in Westminster, with the late F. W. Harbord (a School of Mines man of an earlier generation) and with the late E. F. Law (one of his own fellow-students). This association brought him into intimate contact with the varied metallurgical problems with which practising engineers were being confronted in those days, when thcre were but few to whom they could turn for help and advice. During the First World War (1914-18) Bannister was responsible for a variety of work for the British and Belgian Governments, and he also served as a war-time lecturer at the Royal School of Mines. Then, in 1920, came his appointment as the first occupant of the chair of metallurgy in the University of Liverpool, which he continued to hold with distinction until his retirement in 1941. The Department of Metallurgy was, at that time, unique in being within the Faculty of Engineering. This ensured that its students received tuition both in mechanical and electrical engineering. Moreover, Prof. Bannister arranged that all engineering students should attend courses in metallurgy, particularly of iron and steel. Courses were arranged for naval architects and marine engineers to cover matters such as corrosion and the metallurgy of bearing metals. From time to time he was called as an expert witness in law cases of importance and at times in association with Horatio Ballantyne. During the tenure of his professorship at Liverpool, he had been dean of the Faculty of Engineering from 1924 until 1928 and again from 1935 until 1938.

Bannister undertook to revise, in step with rapid progress, certain metallurgical text-books having an established prestige-Gowland's "Metallurgy of the Non-Ferrous Metals", Sexton's "Metallurgy" and Lunge and Kean's "Technical Methods of Chemical Analysis". He was also the co-author, with $H$. Garland, of "Ancient Egyptian Metallurgy", and he 
also wrote of ancient bronze implements (see Nature, $116,786 ; 1925)$.

Prof. Bannister was a member of many technical institutions and societies - to which he had made numerous contributions-such as the Institution of Mining and Metallurgy, the Iron and Steel Institute, the Institute of Metals (of which he was an original member), the Society of Chemical Industry, and the Liverpool Engineering Society. He was a Fellow of the Royal Institute of Chemistry. Of his many awards, his early successes at the School of Mines have already been mentioned. The Edward Matthey Prize for research followed in 1902, and in 1903 he became a Carnegie Scholar of the Iron and Steel Institute, while in 1912 he was awarded the Consolidated Goldfields of South Africa Gold Medal by the Institution of Mining and Metallurgy, and in 1919 the Bessemer Premium of the Society of Engineers.

Those of us who had enjoyed his friendship from the very early days at South Kensington have always had happy memories of his ever-cheerful outlook and genial personality and a great admiration for his work, both as a teacher and as a practitioner. In these spheres his approach was always characterized by a quickness off the mark and by a directness which left no doubt that he had clearly grasped the essentials of any problem or situation with which he might be faced. His judgments were both shrewd and sure.

Prof. Bannister is survived by his widow, a daughter and a son.
S. W. SMITH

\section{NEWS and VIEWS}

Physical Chemistry at King's College, London: Sir Eric Rideal, M.B.E., F.R.S.

Sir Eric Rideat retires at the end of the present session from the chair of chemistry in the University of London which he holds at King's College. He succeeded the late Prof. A. J. Allmand in 1950. During his tenure of office, Sir Eric has materially strengthened the interests of physical chemistry at King's College, particularly at the postgraduate level. His wisdom and wide experience have also been drawn upon in matters beyond chemistry, and although his period in office has been short he has nevertheless brought great benefit and distinction to the College in many ways. $\mathrm{H}_{e}$ will leave behind many friends. His earlier associations with the University of Cambridge and later with the Royal Institution, as well as his scientific contributions to colloid science and surface chemistry, are well known. His retirement removes from the sphere of academic chemistry one whose scientific work has attained international recognition. 'The subject of colloid science which he did so much to create and develop will be carried on very largely by the great number of physical chemists throughout the world who had the privilege of working under his direction and inspiration. During the past five years, Sir Eric has also held numerous other offices, including those of president of the Chemical Society and chairman of the Advisory Council on Scientific Research and Technical Development of the Ministry of Supply.

Prof. D. W. G. Style

DR. D. W. G. STYLE, who has been appointed to succeed Sir Eric Rideal, was educated at Epsom College and King's College, London. $\mathrm{He}$ worked under the late Prof. A. J. Allmand and afterwards under Prof. M. Polanyi at the Kaiser Wilhelm Institut, Berlin. Since that time, Dr. Style has been at King's College, London, where he now holds a readership. He has made notable contributions to physical chemistry in the fields of photochemistry and spectroscopy. During the Second World War, Dr. Style was seconded for work with the Ministry of Supply.

\section{Metallurgy at Sheffield :}

$$
\text { Prof. R. W. K. Honeycombe }
$$

IT was recently decided that the Department of Metallurgy and the postgraduate school in physical metallurgy in the University of Sheffield should be merged under Prof. A. G. Quarrell, who was given the title of professor of metallurgy. Dr. R. W. K. Honeycombe, senior lecturer in physical metallurgy, has now been appointed professor of physical metallurgy. An Australian by birth, Prof. Honeycombe was educated at Geelong College and the University of Melbourne. As a research student under the direction of Dr. J. Neil Greenwood, he studied the metallurgy of hard alloys of the cemented carbide type. During 1942-47 he was a research officer in the Lubricants and Bearings Section, now the Division of Tribo-Physics, of the Commonwealth Scientific and Industrial Research Organization, and did metallurgical work under the general direction of Dr. F. P. Bowden. Much of this work was aimed at the solution of Service problems arising from the War. However, some research of a more fundamental character was done in collaboration with Dr. W. Boas, including a study of the thermal fatigue of metals and alloys which show anisotropy of thermal expansion. In 1947 Dr. Honeycombe left Australia to take up an I.C.I. fellowship with Dr. E. Orowan's metal physics group in the Cavendish Laboratory, Cambridge, and two years later he was awarded the Royal Society Armourers and Brasiers' Research Fellowship. While at Cambridge, Dr. Honeycombe made a detailed study of the development of deformation bands formed during the plastic deforma. tion of metal crystals, and afterwards, in collaboration with Dr. A. F. Brown, did electron microscope work which led to the discovery of the phenomenon of micro-slip. Since his appointment in 1951 to Sheffield, Dr. Honeycombe has had considerable teaching responsibilities in the recently established postgraduate school of physical metallurgy. He has, nevertheless, continued his research on deformation, paying particular attention to the deformation of crystals of solid-solution and age-hardening alloys. $\mathrm{He}$ is also studying the properties of thorium and its alloys, and the precipitation of carbides in ferritic steels.

\section{The Coblentz Society : a New Society for Infra- Red Spectroscopy}

A NEW society, the Coblentz Society, has been formed in the United States with the object of furthering work in all the aspects of infra-red spectroscopy and of providing a communication centre and forum for the thousands of scientists, research workers 